\title{
Assessment of the Suitability of the Emergency Departments at the Hospitals in the Western Black Sea Region for Pediatric Patients
}

\author{
Batı Karadeniz Bölgesinde Yer Alan Hastanelerin Acil Servislerinin Çocuk Hastalara \\ Uygunluğunun Değerlendirilmesi
}

\author{
Zühal Örnek1, İbrahim Etem Pişkin1, Mehmet Karacı2, Nazmiye Yüksek1, Cem Koray Fırat³, Gonca Handan Üstündağ1 \\ ${ }^{1}$ Bülent Ecevit University Faculty of Medicine, Department of Pediatrics, Zonguldak, Turkey \\ ${ }^{2}$ Beykoz Public Hospital, Clinic of Child Health and Diseases, Istanbul, Turkey \\ 3Şırnak Silopi State Hospital, Clinic of Child Health and Diseases, Şırnak, Turkey
}

\section{Abstract}

Introduction: Timely and accurate medical interventions in emergency departments save lives while a minimal delay may cause irreversible. The aim of this study was to define the appropriateness of the emergency departments at the hospitals in the Western Black Sea region for pediatric patients and to identify the number of personnel and the level of knowledge, and to determine the insufficiency of medicine and technical equipment.

Methods: A questionnaire consisting of 37 questions which evaluated the number of personnel working, the number of pediatric patients examined in the emergency department, architectural design of the emergency department, radiological facilities, triage conditions, interventions that can be performed, courses received, medicine, and equipment for resuscitation, was distributed to the physicians and nurses/medical operators in charge, working in the emergency departments at 20 public and private hospitals that were in operation at the time of the study.

Results: In $80 \%$ of the hospitals included in the survey, pediatric patients that could be treated in outpatient clinics constituted more than $50 \%$ of the emergency admissions. Overnight pediatrician coverage was present in only 5 out of 20 hospitals; general practitioners were on duty at the remaining hospitals.

Conclusion: Ambulance personnel can receive medical support from the closest hospital to stabilize the patient when there is a pediatric patient transport at risk. Therefore, all personnel in emergency departments should receive periodic pediatric emergency training.

Keywords: Pediatric emergency departments, personnel number, radiologic equipments, emergency equipments and medication

\section{Öz}

Amaç: Acil servislerde, doğru ve zamanında yapılan tıbbi müdahale hayat kurtarmakta, en küçük gecikme ise geri dönüşü mümkün olmayan sonuçlara yol açabilmektedir. Bu çalışmada Batı Karadeniz bölgesinde yer alan hastane acil servislerinin çocuk hastalara uygunluğunun, personel sayılarının, bilgi, ilaç ve teknik donanım eksikliklerinin belirlenmesi amaçlanmıştır.

Yöntemler: Çalışmanın yapıldığı tarihte yer alan 20 adet kamu ve özel hastane acil servislerinde çalışan sorumlu hekim, hemşire veya sağlık memurlarına anket formları yöneltildi. Ankete katılanlara, çalışan personel sayısı, acilde bakılan çocuk hasta sayısı, acil servis mimarisi, radyolojik açıdan imkanları, triyaj durumları, yapılabilen girişimler, alınan kurslar ve eğitimler, resüsitasyon ilaç ve ekipmanları ile ilgili toplam 37 soru yöneltildi.

Bulgular: Ankete katılan hastanelerin \%80'inde poliklinik şartlarında işlemleri yapılabilecek çocuk hastalar tüm acil başvurularının \%50'sinden fazlasını oluşturmaktaydı. Yirmi hastanenin sadece 5 tanesinde gece çocuk doktoru mevcuttu, geri kalan hastanelerde pratisyen hekimler görev yapmaktaydı.

Sonuç: Ambulanslar taşıdıkları çocuk hasta eğer bir risk altında ise stabilizasyon için en yakın hastanedeki acil servisten yardım alabilmektedirler, bunun için acil servislerdeki tüm personele periyodik olarak çocuk acil eğitimi verilmelidir.

Anahtar Kelimeler: Çocuk acil servisleri, personel sayısı, radyolojik donanım, acil ilaçlar ve ekipmanları 


\section{Introduction}

Timely and accurate medical interventions in emergency departments save lives; on the other hand, a minimum delay may cause irreversible. 1 Physical structure, availability of equipment and supplies, radiological equipment and adequacy of the working personnel in terms of number and education are important factors for effective and efficient emergency care. The number of patients who present to emergency departments each year in Turkey is equal to the population of the country.

Statistics have revealed that pediatric cases account for about $30 \%$ of the emergency department presentations.2-5 Nevertheless, not all hospitals have equal capacity to serve pediatric patients who have special requirements. Many children receive treatment in emergency departments at the public hospitals together with adult patients. Children should be treated by experienced physicians equipped with knowledge of pediatric emergency and in appropriate conditions when their lives are at risk. ${ }^{2}$

This study is the first and only study aimed at defining the suitability of the emergency departments at the hospitals in the Western Black Sea region for pediatric patients and to identify the number of personnel, level of knowledge (the courses and training attended), and to determine insufficiency of medicine and technical equipment.

\section{Materials and Methods}

Survey forms were distributed to the responsible physicians and nurses/medical operators working in the emergency departments at 20 (14 public and 6 private) hospitals located in the Western Black Sea region. The questionnaire consisted of 37 questions including the number of personnel working (pediatrician, practitioner, nurse and allied health personnel), number of pediatric patients examined (day time: 8.00 AM to 5.00 PM and night time: 5.00 PM to 8.00 AM), architectural design of the emergency department (resuscitation room, examination room and isolation rooms, etc.), radiological facilities, triage conditions and methods, interventions that can be performed, courses and training received (neonatal resuscitation or advanced pediatric life support courses, etc.), and status of emergency medicine and equipment. Survey forms were completed by the investigator during a face-to-face interview. Workload of personnel status is defined as number of patients per a health personnel. This study was approved by the Bülent Ecevit Practice and Research Hospital Ethics Committee. Data obtained were analyzed using the package for the social sciences (SPSS, Inc., Chicago, USA) version 16.0 for Windows. Percentage distribution and the Mann-Whitney
U-test were used in the calculations. A p value of less than 0.05 was considered statically significant.

Six (30\%) hospitals were private and 14 (70\%) were public hospitals. Children who were brought to the emergency room were examined together with adults by the same physician in 16 (89\%) hospitals and were examined by a separate physician in $4(20 \%)$ hospitals. Two $(10 \%)$ of these four hospitals were children's hospitals. The mean number of patients examined in the emergency departments during the night and day were $40.65 \pm 48.21$ (7-140) and 29.35 \pm 27.41 (4-100), respectively. In $80 \%$ of the hospitals included in the survey, pediatric patients with simple health problems (uncomplicated respiratory infections, urinary tract infections, etc.) that could be treated in outpatient clinics constituted more than $50 \%$ of the emergency admissions.

The mean number of personnel (active and passive) dealing with pediatric patients in the emergency departments in all hospitals were $1.40 \pm 1.35$ (0-5) for pediatricians, $4.95 \pm 4.73$ (0-23) for general practitioners, $11.80 \pm 10.49$ (2-49) for nurses, and 4.90 $\pm 5.13(0-24)$ for allied health personnel. Overnight pediatrician coverage was present in only 5 out of 20 hospitals; general practitioners were on duty at the remaining hospitals. More than one general practitioner was present in large public hospitals that received a large number of patients.

No significant differences were found in the mean number of personnel (pediatrician, general practitioner, nurse and allied health personnel) working during the day and at night between public and private hospitals and between hospitals with and without separate pediatric emergency departments (PED). When the hospitals were evaluated in terms of workload of the personnel, no significant differences were found between public and private hospitals, while there was a significant difference in workload of the general practitioners working at nights between hospitals with and without PED $(\mathrm{p}=0.048)$ (Table 1).

In the emergency departments where the survey was conducted, $54.17 \%$ of pediatricians, $7.07 \%$ of general practitioners, $1.20 \%$ of nurses, and $2.04 \%$ of allied health personnel were observed to receive training on advanced life support for children. No significant differences were found between the public and private hospitals in the training status of the personnel. On the other hand, there was a significant difference in the training status of the nurses between the hospitals with and without PED ( $p=0.040)$.

Triage process was applied in 55\% $(n=11)$ of all the hospitals. It was performed by a nurse or a paramedic in 30\% of triageapplied hospitals. None of the centers used special scales. The severity and degree of emergency were determined according to general appearance or vital signs of the patients. 
When the interventional procedures performed in the last six months were evaluated, a significant difference in the number of intubation was found in favor of public hospitals $(p=0.020)$ (Table 2).

On the other hand, when the hospitals were evaluated in terms of invasive interventions, it was remarkable that invasive interventions were never performed in private hospitals, while they were performed in a very few cases in public hospitals. When necessary, intubation was performed by an anesthesiology specialist in $50 \%$ of the cases, an anesthesia technician in $15 \%$, or a general practitioner, emergency medicine specialist physician, and pediatrician, each in $10 \%$ of the cases in descending order of frequency. A significant difference was found between the hospitals where children were examined by seperate physicians for the procedures, such as lumbar puncture (LP) and intraosseous catheter placement. Scheme, patient records, and documents demonstrating appropriate protocols and approach for pediatric patients were present in only $30 \%$ of the hospitals. Appropriate brochures were present in $75 \%$ of the hospitals with PED, which was statistically significant $(p=0.032)$.

The emergency departments at the hospitals included in the study were evaluated for architectural design. The mean number of rooms, beds, and stretchers were $3.15 \pm 1.58(1-6), 7.95 \pm 5.69$ (0-22), and 4.05 $\pm 4.19(0-17)$, respectively. Patient examination rooms, waiting rooms and a general observation room were present in all the hospitals included in the survey. In addition, there were critical care rooms, and separate trauma and isolation/ decontamination rooms in 35\%,25\%, and 10\% of the hospitals, respectively. A significant difference in favor of public hospitals was found in the localization of 112 station units $(p=0.036)$ and separate nurse resting room $(p=0.005)$ when the public and private hospitals were compared in terms of architectural design. Availability of radiological equipment, such as ultrasonography (USG), computed tomography (CT), magnetic resonance imaging (MRI), and direct X-ray graphy as well as 24-hour access to these equipment were also evaluated (Table 3 ). A significant difference was found in the availability of CT in favor of public hospitals ( $p=0.028$ ). For 24-hour access to MRI, a significant difference was observed in favor of public hospitals ( $p=0.014$ ). Availability of radiological equipment and access to these equipment were similar between the hospitals with and without PED. Limited access to USG at night was remarkable in private hospitals. 24-hour access to USG was possible in only 4 out of 20 hospitals and none of those hospitals were private hospitals.

When the equipment in emergency departments were evaluated, otoscope, urine bag, glucometer, electrocardiogram equipment, $\mathrm{O}_{2}$ mask (small size), and defibrillator were present in all emergency services of all hospitals. Radiant heaters were not present in any of the emergency departments. Bilevel positive airway pressure equipment, LP set, Magill forceps, and cricothyrotomy sets were not detected in any private hospitals. Twelve of the emergency departments (60\%) were found to keep more than $50 \%$ of the necessary equipment that should be present in an emergency department; while

Table 1. Workload status of the personnel working in public and private hospitals

\begin{tabular}{|c|c|c|c|c|c|c|}
\hline & \multicolumn{6}{|c|}{ Workload status of the personnel (number of patients/personnel) } \\
\hline & $\begin{array}{l}\text { Public } \\
\text { mean } \pm \text { SD (range) }\end{array}$ & $\begin{array}{l}\text { Private } \\
\text { mean } \pm \text { SD (range) }\end{array}$ & $\mathbf{p}$ & $\begin{array}{l}\text { Without PED } \\
\text { Mean } \pm \text { SD (range) }\end{array}$ & $\begin{array}{l}\text { With PED } \\
\text { mean } \pm \text { SD (range) }\end{array}$ & $\mathbf{p}$ \\
\hline $\begin{array}{l}\text { Pediatrician } \\
\text { (night time) }\end{array}$ & $20.36 \pm 47.82(0-170)$ & $6.67 \pm 16.32(0-40)$ & 0.680 & $31.67 \pm 28.43(0-55)$ & $84.00 \pm 76.86(22-170)$ & 0.275 \\
\hline $\begin{array}{l}\text { Pediatrician } \\
\text { (day time) }\end{array}$ & $23.89 \pm 26.69(0-80)$ & $6.17 \pm 7.44(0-20)$ & 0.185 & $21.15 \pm 18.48(4-50)$ & $40.00 \pm 35.62(8-80)$ & 0.321 \\
\hline $\begin{array}{l}\text { Practitioner } \\
\text { (night time) }\end{array}$ & $43.83 \pm 57.82(0-170)$ & $21.50 \pm 9.69(15-40)$ & 0.729 & $30.82 \pm 41.17(2-160)$ & $84.00 \pm 76.86(22-170)$ & 0.048 \\
\hline $\begin{array}{l}\text { Practitioner } \\
\text { (day time) }\end{array}$ & $31.93 \pm 31.82(0-100)$ & $15.17 \pm 13.95(0-40)$ & 0.591 & $23.00 \pm 25.79(2-100)$ & $49.33 \pm 37.16(8-80)$ & 0.234 \\
\hline $\begin{array}{l}\text { Nurse } \\
\text { (night time) }\end{array}$ & $20.92 \pm 26.57(1-85)$ & $10.97 \pm 3.43(7.33-15)$ & 0.535 & $12.46 \pm 13.19(1-53)$ & $41.83 \pm 39.98(7.33-85)$ & 0.088 \\
\hline $\begin{array}{l}\text { Nurse } \\
\text { (day time) }\end{array}$ & $10.62 \pm 10.37(1-33)$ & $7.27 \pm 6.98(1.66-20)$ & 0.591 & $7.98 \pm 8.45(1-33)$ & $16.17 \pm 11.63(2.67-30)$ & 0.130 \\
\hline $\begin{array}{l}\text { Alliated personnel } \\
\text { (night time) }\end{array}$ & $35.59 \pm 59.98(0-170)$ & $13.83 \pm 6.23(7.50-22)$ & 0.836 & $23.16 \pm 39.96(2-160)$ & $64.25 \pm 27.22(5-170)$ & 0.183 \\
\hline $\begin{array}{l}\text { Alliated personnel } \\
\text { (day time) }\end{array}$ & $15.45 \pm 17.93(0-60)$ & $9.50 \pm 5.72(4-20)$ & 0.934 & $11.64 \pm 9.05(4-33)$ & $27.60 \pm 74.15(2.4-60)$ & 0.454 \\
\hline
\end{tabular}


only 2 emergency departments (10\%) kept more than $75 \%$ of the required equipment.

Among the equipment for children, intubation tubes in all sizes necessary for children were present in all hospitals, newborn and infant balloon masks in 50\%, bone marrow sets in 50\%, LP sets in 25\%, and infusion pumps were present in $75 \%$ of the hospitals with PED. In hospitals with PED, the presence of aero-chambers $(p=0.033)$, monitors $(p=0.046)$, bone marrow sets $(p=0.004)$, pediatric Magill forceps $(p=0.046)$, laryngeal masks ( $p=0.029)$, cricothyrotomy sets $(p=0.046)$, and infusion pumps $(p=0.032)$ were found to be significantly higher.

The hospitals included in the survey were evaluated in terms of the medications that should be present in the emergency departments. Atropine, lidocaine, and sodium bicarbonate among resuscitation drugs; midazolam and diazepam among anti-epileptics; diltiazem, captopril, aspirin, and dopamine among cardiac drugs; metoclopramide among gastroenterology drugs; $\mathrm{H} 2$ receptor antagonists; paracetamol and methimazole among antipyretics; and 0.9\% NaCl, 5-10\% dextrose, and active charcoal used in poisonings were present in all hospitals. The emergency departments at 11 hospitals (55\%) kept more than $75 \%$ of the drugs that were required to be present in an emergency department. When the public and private hospitals were evaluated, glucagon was commonly present in private hospitals $(p=0.012)$, while the presence of rabies vaccine $(p=0.004)$, snake antiserum $(p=0.004)$, and scorpion antiserum $(p=0.0001)$ were significantly more common in public hospitals. In hospitals with PED, presence of succinylcholine $(p=0.032)$, ondansetron $(p=0.049)$, protamine sulfate $(p=0.049)$, and ketamine $(p=0.029)$ and in hospitals without PED, presence of calcium gluconate and narcotic drugs $(p=0.004)$ were found to be significantly higher.

When the hospitals were evaluated generally in terms of equipment and drugs together, there were no emergency services that met all the conditions, however, there were 4 hospital emergency departments (20\%) that met $70 \%$ of the conditions required. Two of these 4 hospitals were private hospitals.

\section{Discussion}

There has been a steady increase in the number of applications to emergency departments in recent years. However, most emergency departments have not been designed for children and do not have the capacity to meet the special needs of children. Most pediatric patients requiring emergency treatment are examined at the same place with adult patients and by the same physician. A great majority of those patients presenting to emergency departments have been diagnosed to be simple cases with no emergency conditions. One of the most important reasons for this condition is that parents use emergency departments for general health services and assess the diseases of their children as severe. Non-emergency applications, such as those mentioned above, increase the patient volume in emergency departments and decrease the quality of medical care. The rate of patients not requiring emergency medical treatment has been evaluated in various studies performed in the emergency departments in Turkey. This rate has been reported to be $19.5 \%$ at Yüzüncü Yıl University Hospital, 32.2\% at Dokuz Eylül University Hospital, and $40.1 \%$ at Trabzon Sürmene State Hospital.6-8 Similarly, in our study, pediatric patients whose treatments could be performed in outpatient setting constituted

Table 2. Interventional procedures performed in pediatric patients in the emergency department

\begin{tabular}{|c|c|c|c|c|c|c|}
\hline Interventional procedures within the last 6 months & $\begin{array}{l}\text { Public } \\
n^{*}(\%)\end{array}$ & $\begin{array}{c}\text { Private } \\
n *(\%)\end{array}$ & $\mathbf{p}$ & $\begin{array}{l}\text { Without PED } \\
n^{*}(\%)\end{array}$ & $\begin{array}{l}\text { With PED } \\
n^{*}(\%)\end{array}$ & $\mathbf{p}$ \\
\hline Intubation & $8(57.1)$ & 0 & 0.020 & $5(31.2)$ & $3(75)$ & 0.119 \\
\hline Lumbar puncture & $1(7.1)$ & 0 & 0.513 & 0 & $1(25)$ & 0.046 \\
\hline Intraosseous catheter placement & $1(7.1)$ & 0 & 0.513 & 0 & $1(25)$ & 0.046 \\
\hline
\end{tabular}

Table 3. Comparison of radiological equipment and accessibility between the hospitals

\begin{tabular}{|c|c|c|c|c|c|c|}
\hline & \multicolumn{3}{|c|}{ Depending on whether the radiological equipment is present } & \multicolumn{3}{|c|}{ Equipment based 24-hour access } \\
\hline & Public $(n=14)$ & Private $(n=6)$ & $\mathbf{p}$ & Public & Private & $\mathbf{p}$ \\
\hline USG & $12(85.7 \%)$ & $5(83.3 \%)$ & 0.894 & $4(28.6 \%)$ & $0(0 \%)$ & 0.152 \\
\hline MRI & $3(21.4 \%)$ & $4(66.7 \%)$ & 0.058 & $3(21.4 \%)$ & $0(0 \%)$ & 0.014 \\
\hline Direct graphy & $14(100 \%)$ & $5(83.3 \%)$ & 0.127 & $14(100 \%)$ & $4(66.7 \%)$ & 0.094 \\
\hline
\end{tabular}


more than $50 \%$ of all the emergency admissions. With this result, we believe that emergency departments have begun to be used more frequently for simple cases.

The most important factor for the success of pediatric emergency care is trained manpower (physicians, nurses, etc.) in adequate quantity. When the mean number of personnel responsible for pediatric patients in the emergency departments of all hospitals was evaluated, it was noted that pediatricians and general practitioners were not present in some hospitals. Although there was no significant difference between the hospitals in respect to the work load of health personnel (number of patients per personnel), the work load was found to be quite high. We believe that the number of hospital staff members should be rearranged according to the volume of the hospitals.

More than $80 \%$ of the mortalities in children are due to the sudden development of conditions and, early diagnosis of highrisk patients decreases morbidity and mortality. ${ }^{9}$ This, in turn, demonstrates that experience and training of the personnel working in PED are of great importance. The knowledge of health personnel dealing with pediatric patients in emergency departments regarding frequently changing issues, such as resuscitation, and basic and advanced life support in children should be updated. In a study performed in Malawi in 2006, it was demonstrated that mortality rate among hospitalized children under 5 years of age was decreased from 10-18\% to $5-8 \%$ through the efforts of personnel trained in pediatric emergencies. 10 Only $57.14 \%$ of the pediatricians working in the emergency departments at the hospitals included in the survey participated in courses on advanced life support in children, while this rate progressively decreased among other health personnel. With this finding, it is suggested that the number of trained physicians and other personnel should rapidly be increased and periodical continuity of training should be maintained in order to decrease morbidity and mortality in children brought to the emergency services.

Emergency department personnel must develop his/her skills in life-saving invasive interventions, in addition to receiving further training. In the present study, it was seen that interventional procedures were performed in very few cases and in few centers. The most common intervention performed was intubation which was more commonly done by anesthesiologists. The reason for this might be the low number of pediatricians and general practitioners, the high work load of those personnel, and the inadequacy of their training. The number of general practitioners working in PED has known to gradually decrease, especially due to the recently emerging family physician system.

Recently, triage has been demonstrated to be important since patients are noted to use the emergency services with nonemergent causes and, crowds put the safety of patients in danger. The triage of a patient brought to an emergency department should be performed by a trained nurse or physician. 11,12 Triage was reported to be performed in 55\% $(n=11)$ of all the hospitals. It was performed by a nurse or a paramedic in 30\% of triage-applied hospitals.

Only 30\% of the hospitals included in the study used appropriate protocols and treatment schemes, patient records, and documents for pediatric patients. Most of these documents $(75 \%)$ were present in the hospitals with PED. Since children greatly vary in size and treatment schemes according to weight, erroneous or high-dose drug applications might occur (for example, mistakes in converting milligrams to milliliters). This condition might cause a risk of death more commonly in children compared to that in adults. ${ }^{13}$

Emergency departments at the hospitals in Turkey are generally prepared to suit the needs of adult patients. Considering that children are treated in the same emergency departments, obtaining appropriate protocols and schemes demonstrating necessary approaches as well as increasing the number of those protocols and schemes are necessary in order to decrease the rate of errors.

The architectural structure, radiological equipment, and the availability of equipment and medicines, as well as the number and training status of personnel are important factors in achieving an efficient and effective work environment in emergency departments. In a study performed in Turkey, it was emphasized that emergency departments have to offer most of the medical services provided in hospitals since they are the centers at which non-emergency cases, as well as emergency cases, are treated due to direct accessibility. Therefore, it was stated in that study that emergency clinics of the hospitals should be architecturally planned to provide health services for the stable patient population as well. ${ }^{14}$ In our study, patient examination rooms, waiting rooms, general observation rooms, and intervention rooms were present in all the hospitals evaluated. In addition, critical care rooms and separate trauma and isolation/ decontamination rooms were present in 35\%,25\%, and $10 \%$, respectively. Radiological imaging units to expedite the diagnostic stages were present in the emergency departments in $7.4 \%$ and $50 \%$ of public and private hospitals, respectively. Radiological examinations were performed at radiology departments outside the emergency services in the rest of the hospitals.

The availability of USG at night was limited in all hospitals. The reason for this might be the fact that radiological examinations such as CT were performed more frequently, but CT was preferred over USG, since a radiologist is required to perform USG.

Various lists have been published many times for the pediatric equipment and medicine that are required to be present in emergency departments. On the contrary, most of the 
pediatric departments have remained unprepared for pediatric emergency cases. In a study from Canada, equipment for basic pediatric resuscitation was detected to be highly inadequate for a wide variety of reasons. 3 In our study, there were 12 emergency departments (60\%) keeping more than $50 \%$ of the required equipment in an emergency department, while only two emergency departments of the hospitals kept more than $75 \%$ of the required equipment. According to this finding, the equipment intended to be used on both children and adults was found to be inadequate at a high rate. When considering this in addition to the scarcity of the number of interventional procedures, it is difficult to decide whether this is due to the unwillingness of the doctors to perform interventions, the inadequacy of experience, or the scarcity of equipment due to various causes, such as hospital debt. Medicines for resuscitation, cardiac drugs, antipyretics, and most of the fluids were present in all the hospitals included in the study. The number of hospital emergency departments providing more than $75 \%$ of the required medicine in an emergency department was 11 (55\%).

There was no single hospital providing all the required equipment and medicines that should be present in an emergency department. This result, therefore, demonstrates that deficiencies in emergency departments should be revised to meet the requirements of both pediatric and adult patients.

\section{Conclusion}

It should be kept in mind that children are not just small adults, and although pediatric patients are not accepted in all emergency departments, there is always a risk to be obliged to provide care to a child in critical condition. Therefore, all personnel in emergency departments should receive periodical training in pediatric emergency; a child-friendly environment should be created in emergency departments; pediatric protocols should be followed; appropriate pediatric equipment and supplies should be provided in those departments and, those services should be made more suitable for pediatric patients.

\section{Ethics}

Ethics Committee Approval: This study was approved by Bülent Ecevit Practice and Research Hospital's Ethics Comittee. Informed Consent: No patient information is used in our study. This is a survey study.

Peer-review: Externally peer-reviewed.

\section{Authorship Contributions}

Surgical and Medical Practices: Mehmet Karacı, Gonca Handan Üstündağ, Concept: Ibrahim Etem Pişkin, Zühal
Örnek, Design: Zühal Örnek, Ibrahim Etem Pişkin, Data Collection or Processing: Cem Koray Firat, Analysis or Interpretation: Zühal Örnek, Literature Search: Zühal Örnek, Nazmiye Yüksek, Writing: Zühal Örnek

Conflict of Interest: No conflict of interest was declared by the authors.

Financial Disclosure: The authors declared that this study received no financial support.

\section{References}

1. American Academy of Pediatrics, Committee on Pediatric Emergency Medicine. Overcrowding crisis in our nation's emergency departments: is our safety net unraveling? Pediatrics. 2004;114:878-88.

2. Commitee on the future of emergency care in the USA', Emergency Care for Children: Growing Pains. Washington D.C.: The National Academies Press. First ed. 2006.

3. McGillivray D, Nijssen-Jordan C, Kramer MS, Yang H, Platt R. Critical pediatric equipment availability in Canadian hospital emergency departments. Ann Emerg Med. 2001;37:371-6.

4. Weiss HB, Marthers LJ, Forjuoh SN, Kinnane JM. Child and adolescent emergency department visit data book. Pittsburgh: Center for Violence and Injury Control, Allegheny University of Health Services; 1997.

5. Yılmaz HL. Dünya'da ve Türkiye'de çocuk acil bilim dalının gelişimi. içinde: Karaböcüoğlu M, Yılmaz HL, Duman M (ed.ler). Çocuk Acil Tıp: 1. Baskı. İstanbul, İstanbul Tıp Kitapevi, 2012:3-6.

6. Edirne T, Edirne Y, Atmaca B, Keskin S. Patient Characteristics at the Emergency Department, Medical School of Yuzuncu Yil University. Van Medical Journal. 2008;15:107-11.

7. Ersel M, Karcıoğlu Ö, Yanturalı S, Yürüktümen A, Sever $M$, et al. Emergency Department utilization characteristics and evaluation for patient visit appropriateness from the patients' and physicians' point of view Turk J Emerg Med. 2006;6:25-35.

8. Ayvaz A, Güngör N, Topbaş M, Yıldızlar O, Çan E, et al. Characteristic of the Child Patients Admitted to Emergency Department in Sürmene Government Hospital, Trabzon. Cumhuriyet Medical Journal. 2007;29:156-62.

9. Uzel N. Acil çocuk hastaya yaklaşım. Iç̧inde: 2. Acil pediatri ve çocuk yoğun bakım toplantı kitabı, 2001:13-5.

10. Molyneux E, Ahmad S, Robertson A. Improved Triage and emergency care for children reduces inpatient mortality in a resource constrained setting. Bull World Health Organ. 2006;84:314 9.

11. Boran P, Tokuç G, Çoban Büyükkalfa D, Taşkın B, Pişgin B. Evaluation of the Patients Admitted to the Pediatric Emergency Department. J Child. 2008;8:114-6.

12. Northington WE, Brice JH, Zou B. Use of an emergency department by nonurgent patients. Am J Emerg Med. 2005;23:131-7.

13. Hughes RG, Edgerton EA. Reducing pediatric medication errors: Children are especially at risk for medication errors. Am J Nurs. 2005; 105:79-80.

14. Deniz T, Aydınuraz K, Oktay C, Saygun M, Ağalar F. The evaluation of academic emergency department design. Ulus Travma Acil Cerrahi Derg. 2007;13:28-35. 